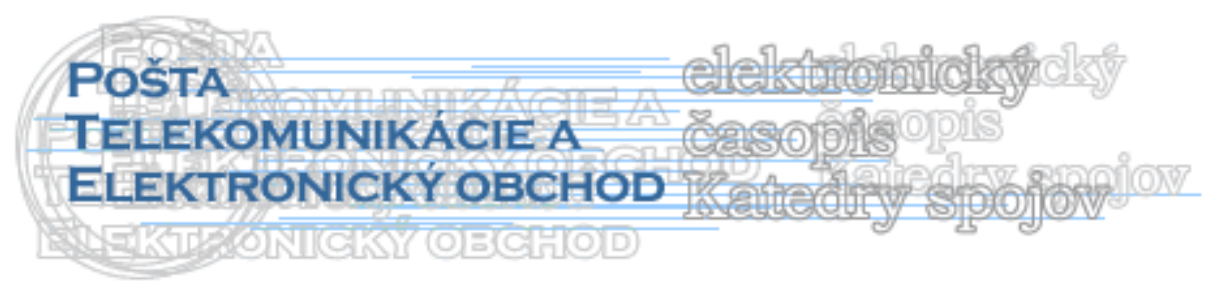

\title{
SPAM - HORÚCI PROBLÉM INTERNETOVÉHO SVETA
}

\author{
Andrea Belanová*
}

\section{Na úvod}

Väčšina $\mathrm{z}$ nás sa v poslednom čase stále častejšie st’ažuje na plnú schránku spamu. V súčasnosti tvorí spam až 80 \% elektronickej pošty. Málokto si však uvedomuje, že okrem strácania času predstavuje spam aj ekonomický a celospoločenský problém. Spoločnosti musia na riešenie tohto problému vynakladat' nemalé prostriedky. Spomal'uje sa tak rast nielen digitálnej ekonomiky.

\section{1. Čo je spam?}

Spam (alebo "junk mail”) je anglický termín pre zaplavovanie internetu mnohými kópiami tej istej správy, ako pokus o prienik do pozornosti l'udí, ktorí by si túto správu inak nevyžiadali. Väčšinou sa jedná o rôzne komerčné e-maily, ponukové listy, prezenácie pochybného produktu, ponuku práce, propagáciu pololegálnych služieb, ret’azové e-maily a pyramídové hry. Pre odosielatel'a je vel'mi jednoduché - a najmä lacné - poslat' správu. Väčšinu poplatkov s tým spojených však musí uhradit' adresát.

Vzhl'adom na to, že bez lekárskeho predpisu môžeme získat' okrem iného aj antidepresíva, predstavuje spam celospoločenský problém.

Spam vo väčšine prípadoch končí vymazaním. Ked' však začne do e-mailovej schránky pribúdat' denne 100 až 150 spamov, začína to byt' nepríjemné. Obvykle uviaznu v špeciálnej zložke, takže jedným kliknutím na tlačidlo sú vymazané. Ale len do chvíle, kým nepríde d’alšie. Spam, okrem toho, že je zlodejom času, spôsobuje aj značné ekonomické škody.

Spammeri (l'udia, ktorí sa spamom živia) získavajú e-mailové adresy pomocou „robotov“, ktorí ich vyhladávajú v internete napr. v rôznych diskusných fórach, na stránkach vyžadujúcich registráciu, atd'. Neexistuje spôsob, akým by sa jednotlivec dokázal ubránit' proti „zneužitiu“ e-mailovej adresy. Rozhodujúca úloha je preto na poskytovatel'och internetových pripojení, telekomunikačných operátoroch a vel'kých organizáciách, cez ktoré „preteká“ vel'ké množstvo elektronickej pošty.

Phishing je správa tváriaca sa ako oznam od banky alebo iného dôveryhodného subjektu a žiada o zadanie osobných údajov. Tie sú následne zneužívané rôznymi spôsobmi.

Okrem klasického internetového spamu je vel'mi pravdepodobný aj vzostup mobilného spamu. Umožní to predovšetkým pokročilejšia technológia mobilných telefónov. Tie sa pomocou lepšej integrácie s počítačmi stanú novým terčom útokov.

Istú komplikáciu predstavuje aj nástup obrázkového spamu. Antispamové programy sú schopné „,prečítat““ a odlíšit’ obrázkový spam od normálnej pošty len do určitej miery.

\section{Spam ako ekonomický problém}

\footnotetext{
* Ing. Andrea Belanová, AGO spol. s r.o., Kysucký Lieskovec 202, 02334 Kysucký Lieskovec tel.: +4231127 , fax: +4231127

e-mail: andrea_laura@pobox.sk
} 
Spam sa teda stáva závažným problémom vo svete internetu a jeho rozsah bude v najbližšom období len narastat'. Na boj proti spamu zatial' nebolo predstavené efektívne riešenie. Preto ešte stále musia užívatelia elektronickej pošty vynakladat' množstvo prostriedkov na hardware, software a technickú podporu.

Spam tvorí podl'a výskumov Organizácie pre hospodársku spoluprácu a rozvoj až $80 \%$ všetkých e-mailov. Spôsobuje tak vel'kú škody jednotlivcom a najmä firmám, ktoré musia vynakladat' vel'a času a finančných prostriedkov na to, aby sa proti spamu bránili.

Spam okrem upchávania sietí tak „podkopáva“ dôveryhodnost' internetu ako média a spomal'uje rast digitálnej ekonomiky.

Hlavne u USA už dosiahol spam rozmery záplavy, preto sa vynorili aj organizácie a kampane, ktoré bojujú proti spammerom na internete. Definovali niekol'ko dôvodov, prečo je spam problémom:

- Zvyšovanie nákladov a plytvanie prostriedkami adresátov. Ak máte pripojenie po telefónnej linke, platíte za prenos informácii, ktoré nechcete a ktoré vás nezaujímajú.

- Podvody. Autori správ si uvedomujú, že ich správy nie sú v poštových shránkach vítané, preto sa snažia použit' rôzne triky, aby si používatel' správu bol ochotný prečítat', napr. posielajú poštu pod fiktívnym menom, alebo v mene nejakej známej organizácie, aby si zabezpečili, že ich správu si l'udia budú ochotní prečítat'.

- Vytlačenie obyčajného e-mailu. Naozaj potrebné správy je problém poslat' v dôsledku pret’ǎenia liniek.

- Rušivý vplyv. Ak sa proti spamu nebude bojovat', rozšíri sa ako záplava do našich poštových schránok.

- Etika. Spam je založený na kradnutí inofrmácii, podvádzaní, lži a presúvaní platieb na adresátov.

\section{Dostupnost' riešenia}

Bayesov filter je schopnost' odchytit' takmer 100 \% spamu. Jeho slabým miestom je však rýchlost', resp. pomalost' filtrácie. Odchytávanie spamu je tak hardwarovo ako i časovo náročnou záležitost'ou. Práve tieto parametre sú najslabšími miestami súčasných antispamových riešení. Rýchlejšia filtrácia vel'kého množstva pošty si vyžaduje viac rýchlejších a drahších serverov. Hardvérová náročnost' sa teda odráža aj na celkových nákladoch.

\section{Riešenia}

Nedávno bolo predstavené prvé skutočne výkonné a efektívne riešenie v boji proti spamu. Program je určený pre poskytovatel'ov internetového pripojenia, telekomunikačných operátorov a vel'ké organizácie, ktorí denne spracúvajú vel'ké množstvo e-mailov, a teda aj spamu.

\section{Existuje prevencia?}

Vyvarovat' sa spam je možno dodržiavaním nasledovných zásad:

- vytvorením účtu na niektorom freemailovom serveri a jeho presmerovaním do svojej e-mailovej schránky. Správa zaslaná na freemailovú adresu príde do skutočnej schránky bez toho, aby o tom odosielatel' vedel. Ak začne chodit' spam na túto adresu, jednoducho sa zruší a vytvorí sa nová,

- pri registrácii na menej dôveryhodných serveroch zadávat' výhradne freemailovej adresy,

- pri zadávaní kontaktnej e-adresy na domovskú stránku použit’ tvar čitatel’ný len pre človeka, nie počítač (napr. riaditel (zavinac) firma.sk),

- pri písaní do e-mailových konferencií používat’ freemailovej adresy, 
- neotvárat' nevyžiadaných správ, najmä vo formáte HTML a to ani do náhl'adu. Často totiž obsahujú kód, ktorý odosielatel'ovi bez vedomia potvrdí, že správa bola otvorená a že e-mailová adresa je "živá".

\section{Legislatívne pokrytie v SR a v Európskej únii}

Trestné stíhanie v SR bude pokračovat' podl'a nasledovných národných a štátnych zákonov zameraných na spammerov:

- Zákon o reklame č. 147/2001 Z. z. v znení neskorších predpisov

- § 3 ods. 4 písm. a: „Reklama nesmie zneužívat' dôveru spotrebitel'a, nedostatok jeho skúseností alebo vedomostí.“

- § 3 ods. 6: „Reklama sa nesmie šírit’ automatickým telefonickým volacím systémom, telefaxom a elektronickou poštou bez predchádzajúceho súhlasu ich uživatel'a, ktorý je príjemcom reklamy.“

- § 3 ods. 7: „Reklama sa nesmie šírit’ adresne, ak adresát doručenie reklamy vopred odmieta."

- Zákon o elektronickom obchode č. 160/2005 Z. z. v znení neskorších predpisov

- § 4 ods. 6: „P Poskytovatel' služieb nesmie doručovat’ informácie komerčnej komunikácie elektronickou poštou, ak si ich príjemca služby vopred nevyžiadal.“

- Zákon o elektronickej komunikácii č. 610/2003 Z. z.

Podl'a Smernice Európskej komisie 2002/58/EC o spracovaní osobných údajov a ochrane súkromia voblasti elektronických komunikácí́ vo všeobecnosti existujú v Európskej únii dva základné prístupy, podl'a ktorých môže elektronická pošta marketingového charakteru prebiehat':

- „Opt-in“ - posielanie elektronickej pošty marketingového charakteru len s predchádzajúcim súhlasom. (Implementované v Rakúsku, Belgicku, Dánsku, Fínsku, Nemecku, Grécku, Mad'arsku, Taliansku, Slovinsku a Španielsku).

- „Opt-out“ - zákaz maskovania identity a podmienku, že všetky priame marketingové správy musia obsahovat' platnú adresu.

\section{Záver}

Ak poskytovatelia internetových služieb zavedú zmluvné podmienky služby a budú rušit' kontá tých používatel'ov, ktorých počítače sú vysielačmi spam, a ak si používatelia budú primerane chránit' svoje počítače, našli sme jeden spôsob, ako zlepšit' súčasný stav.

Dnes si však povedzme o situácii so spam otvorene: bude horšie, pretože už bolo lepšie.

\section{Použitá literatúra}

[1] KOVÁČIK, M..: Prognózy a trendy IT, Hospodárske noviny, [20.3.2007], 27 str.

[2] Spam - nevyžiadaná pošta, (http://www.ehs.sk/support/spam.phtml), [26.3.2007]

[3] Nevyžiadaná pošta od Network.sk, (http://www.izsak.net/weblog/198/nevyziadana-postaod-network-sk), [16.3.2007]

[4] STAŇO, M.: Sociálne aspekty IKT, SPAM - teror našich poštových schránok, (http://user.edi.fmph.uniba.sk/winczer/SocialneAspekty/Stano.htm), [06.03.2001]

[5] Spam, (http://www.telecom.gov.sk/index/index.php?ids=3771), [12.03.2007] 